\title{
Increasing In Vitro Shoot Elongation and Proliferation of 'G.30' and 'G.41' Apple by Chilling Explants and Plant Growth Regulators
}

\author{
Fang Geng \\ College of Horticulture, Nanjing Agriculture University, Nanjing, Jiangsu \\ 210095, China; and School of Food and Agriculture, University of Maine, \\ Monmouth, ME 04259
}

Renae Moran ${ }^{1}$ School of Food and Agriculture, University of Maine, Monmouth, ME 04259

\author{
Michael Day \\ School of Forest Resources, University of Maine, Orono, ME 04469
}

William Halteman

Department of Mathematics and Statistics, University of Maine, Orono, ME 04469

Donglin Zhang

Department of Horticulture, University of Georgia, Athens, GA 30602

Additional index words. dormancy, gibberellin, cytokinin, brassinosteroid, Malus $\times$ domestica, micropropagation, rootstock, shoot growth

\begin{abstract}
These studies were conducted to determine the most effective methods for increasing shoot elongation during the initial proliferation stage of micropropagation in two dwarfing apple, Malus $\times$ domestica (Borkh.), rootstock cultivars. Several experiments were conducted to compare explant collection date, exposure to chilling $\left(5 \pm 1^{\circ} \mathrm{C}\right)$ temperatures, and varying concentrations of plant growth regulators in Murashige and Skoog (MS) media. Microshoot growth of 'Geneva 41' ('G.41') was very low and unaffected by chilling duration from 0 to 8 weeks or by gibberellic acid $\left(G_{3}\right)$ concentration from 0 to $1.0 \mathrm{mg} \cdot \mathrm{L}^{-1}$, but was improved by an additional subculture which increased shoot length from 1 to 15 mm. In 'Geneva 30' ('G.30'), shoot elongation was most affected by date, chilling explants, and by optimizing cytokinin concentration and type. Explant collection date in April increased shoot growth compared with August or November. Microshoot growth of 'G.30' was increased by chilling nodal explants for 4 and 6 weeks when explants were collected in August and November, but not in April. Eight weeks chilling was detrimental for explants collected in April, and generally had little or no effect with August and November. The cytokinin 6-benzylaminopurine (BA) increased shoot number to a greater extent than thidiazuron (TDZ) or zeatin (ZT), and was also more effective for increasing shoot elongation with concentrations of 0 to $2.0 \mathrm{mg} \cdot \mathrm{L}^{-1}$. In ' $\mathrm{G} .30$ ', $\mathbf{G A}_{3}$ increased shoot growth at the optimum concentration of $\mathrm{BA}$, but not with lower concentrations. 'G.30' microshoots were fewer and shorter with 24-epibrassinolide (EBR) at concentrations of 0.1 and $1.0 \mathrm{mg} \cdot \mathrm{L}^{-1}$. Chemical names: N-phenyl-N'(1,2,3-thiadiazol-5-yl)urea (TDZ), 6-(4-hydroxy-3-methylbut-2-enylamino)purine (ZT).
\end{abstract}

Micropropagation can rapidly increase numbers of stock plants, particularly for new cultivars that are available in limited

Received for publication 20 Jan. 2016. Accepted for publication 21 Apr. 2016.

This project was funded in part by a grant from the Maine Agricultural Center and by the USDA National Institute of Food and Agriculture Hatch project NC140.

Mention of a trademark, proprietary product, or vendor does not constitute a guarantee or warranty of the product, and does not imply its approval to the exclusion of other products that also may be suitable. Maine Ag. and Forest Exp. Stn. no. 3479. ${ }^{1}$ Corresponding author. E-mail: rmoran@maine.edu. quantities. Because of their genetic stability and potential for high proliferation, singleand multiple-node shoot pieces are commonly used as explants for in vitro propagation of apple (De Klerk, 1992). Efficient propagation using this method depends on rapid shoot development and elongation following establishment. However, many important apple rootstock cultivars exhibit a lack of shoot elongation during the proliferation phase with the foliage appearing as a rosette (Aklan et al., 1997; Geng et al., 2015; Lane and McDougald, 1982; Pua et al., 1983; Webster and Jones, 1991). A prolonged period in sterile culture can promote shoot growth, but adds to the duration and cost of micropropagation. Lack of shoot growth during the proliferation stage limits the entire propagation process, but causal factors remain unknown. Identifying methods for rapid and efficient proliferation during initial phases of culturing is needed to increase propagation efficiency.

Shoot growth during the proliferation stage is more rapid when explants are collected in spring compared with later dates in summer or fall (Hutchinson, 1984; Kane, 2005; Modgil et al., 1999). The cause of the reduction of in vitro shoot growth with summer and fall collection dates is not clear, but may be due to the onset of dormancy (Borkowska, 1986; De Klerk, 1992), which is typically overcome by exposing micropropagated plants to low $\left(<7^{\circ} \mathrm{C}\right)$, nonfreezing temperatures (Howard and Oehl, 1981; Isutsa et al., 1998; Kavanagh et al., 1993). Chilling increases in vitro shoot growth when it occurs to stock plants of Rubus (Wu et al., 2009), explants of apricot (Koubouris and Vasilakakis, 2006), and shoot proliferation cultures of Prunus tenella (Bouza et al., 1992). Chilling 'Jork' apple shoot cultures during shoot proliferation increases growth of shoots that have no obvious growth inhibition (De Klerk, 1992), but has not been tested on apple cultivars with obvious signs of stunted growth.

The effect of chilling duration during apple nodal culture establishment has not been tested, but increasing chilling from 1 to 2 weeks increases subsequent shoot proliferation in established cultures (De Klerk, 1992). In the case of apricot explants (Koubouris and Vasilakakis, 2006), a short chilling duration of 4 to $12 \mathrm{~d}$ is sufficient to increase shoot number, but not elongation. In sour cherry, 6 to 8 weeks was optimum for promoting shoot growth, but longer than 8 weeks was detrimental (Borkowska, 1986).

Cytokinin in the media is necessary for proliferation, but can inhibit shoot elongation at concentrations that promote rapid increase in shoot number (Elliott, 1972; Hutchinson, 1984). In general, BA is preferred to other cytokinin types, and the optimum concentration is $1 \mathrm{mg} \cdot \mathrm{L}^{-1}$ to promote both an increase in shoot number and shoot length of apple (James and Thurbon, 1981; Kereša et al., 2012; Lane and McDougald, 1982; Pua et al., 1983). TDZ causes greater proliferation than $\mathrm{BA}$, but can also inhibit elongation to a greater extent (Huetteman and Preece, 1993; Marin et al., 1993; van Nieuwkerk et al., 1986). Compared with BA, kinetin results in fewer but longer shoots (Lundergan and Janick, 1980) and may be more effective for genotypes that display poor shoot elongation.

Adding auxin or $\mathrm{GA}_{3}$ to the media can increase shoot length (Kane, 2005; Reeves et al., 1985), but the effect is variable and dependent on a number of other factors such as the concentration of cytokinin in the media. Pua et al. (1983) reported that low concentration of $\mathrm{BA}$ combined with $\mathrm{GA}_{3}$ increases shoot number and length, but $\mathrm{GA}_{3}$ decreases shoot length with a high BA concentration in the media. Increasing concentration of indole-3-butyric acid (IBA) increases shoot length, but only when $\mathrm{GA}_{3}$ is 
also present (Yepes and Aldwinckle, 1994). A greater understanding of the $\mathrm{GA}_{3}$ effectiveness and interactions with other growth regulators may improve propagation of recalcitrant genotypes.

Brassinosteroid promotes in vitro shoot multiplication and elongation in apple when applied directly to foliage (Schaefer et al., 2002), but this method is labor intensive and increases the chance for contamination. When added to media, EBR can promote shoot elongation at a concentration below $1 \mathrm{mg} \cdot \mathrm{L}^{-1}$ in Dioscorea sp. (Engelmann-Sylvestre and Engelmann, 2013) and Capsicum annuum (Franck-Duchenne et al., 1998). As an additive to media, it has not been tested for increasing in vitro shoot growth in apple cultivars that display shoot growth inhibition.

The purpose of these studies was to fill substantial gaps in our understanding of the effects of explant collection date, chilling nodal explants, and media concentration of the plant growth regulators $\mathrm{GA}_{3}, \mathrm{EBR}, \mathrm{BA}$, ZT, and TDZ on shoot growth of 'G.30' and 'G.41' apple during the initial proliferation stage of micropropagation. The focus of this research was to identify factors that improve initial shoot proliferation. Therefore, the effect of these factors on continued proliferation and subsequent rooting was not examined.

\section{Materials and Methods}

Plant materials. One- and two-year-old 'G.30' and 'G.41' apple trees, that served as stock plants, were overwintered in cold storage in the dark at $1 \pm 1{ }^{\circ} \mathrm{C}$ as potted plants from Oct. 2010 to Apr. 2011 and again from Oct. 2011 to Mar. 2012. Trees were then grown in a heated greenhouse at the University of Maine (Orono, ME) to serve as stock plants. Day temperature ranged from 20 to $35{ }^{\circ} \mathrm{C}$ and night temperature from 18 to $25^{\circ} \mathrm{C}$. In 2013, 1-year-old trees from a commercial nursery were potted in March and grown in the heated greenhouse to serve as stock plants. Propagation on protected Geneva ${ }^{\circledR}$ rootstock material was conducted with consent from the current lead breeder. The rootstocks were planted into 3.79-L plastic containers with Metro-mix 560 (Scotts-Sierra Horticultural Products Company, Marysville, $\mathrm{OH}$ ) in 2011 and 2012, and Fafard 3B mix (Sungro, Agawam, MA) in 2013, and watered as needed. The young and nonlignified shoots were cut off in the early morning as the raw explants for establishing aseptic in vitro shoots. To avoid the effects of shoot age, cuttings were taken from the initial flush of growth or from subsequent new shoot growth following previous tipping.

Aseptic culture establishment. Collected shoots were immediately placed in a beaker containing distilled water and transferred to a tissue culture laboratory. To reduce transpiration, collected shoots were defoliated and trimmed to 10 - to $15-\mathrm{mm}$ length with one or two nodes. The nodal segments were firstly surface-disinfested for $30 \mathrm{~s}$ in $70 \%$ alcohol and then soaked for $10 \mathrm{~min}$ in an aqueous solution of $10 \%$ bleach $(6.0 \%$ sodium hypochlorite; The Clorox Company, Oakland, CA) and several drops of Tween 20 (Agdia $^{\circledR}$ Inc., Elkhart, IN). All nodal cuttings were rinsed three to five times under a laminar hood using sterilized, distilled water.

Murashige and Skoog (1962) basic media supplemented with $30 \mathrm{~g} \cdot \mathrm{L}^{-1}$ sucrose and 8 g. $\mathrm{L}^{-1}$ agar (Sigma Chemical Co., St. Louis, MO) was used in all experiments. The $\mathrm{pH}$ of all media was adjusted to $5.8 \pm 0.2$ with $1 \mathrm{M}$ $\mathrm{NaOH}$ or $1 \mathrm{~m} \mathrm{HCl}$ solution after adding agar. An aliquot of $10 \mathrm{~mL}$ of the medium was pipetted into glass tubes, capped and autoclaved at $121{ }^{\circ} \mathrm{C}$ for $30 \mathrm{~min}$. Establishment media contained no plant growth regulators. For experimental proliferation media, cytokinins or IBA were added to media before autoclaving, but $\mathrm{GA}_{3}$ and EBR were added after a period to allow cooling to a temperature of 60 to $70^{\circ} \mathrm{C}$. To prevent contamination by the nonautoclaved $\mathrm{GA}_{3}$ and $\mathrm{EBR}$, they were first dissolved in 95\% ethanol.

Each nodal cutting was dissected and vertically inserted into $60-\mathrm{mL}$ disposable culture tubes (borosilicate glass, $25 \times 150$ $\mathrm{mm}$ ) containing $10 \mathrm{~mL}$ previously prepared MS culture media for establishment. Tubes with explants were set in racks and sealed in a plastic bag. Phenolic browning was minimized by growing stock plants in a greenhouse without supplemental lighting and by selecting the youngest portion of new shoots. Before and after chilling treatment, cultures were arranged randomly on shelves under cool-white fluorescent lamps (Philips $60 \mathrm{~W} 4$ $\mathrm{ft} \mathrm{T} 8$ ) and incubated at a temperature of $27.2 \pm$ $1.9{ }^{\circ} \mathrm{C}$ with a 16 -h photoperiod. Photosynthetic photon flux was $25 \mu \mathrm{mol} \cdot \mathrm{m}^{-2} \cdot \mathrm{s}^{-1}$ as measured using a quantum light meter (LQM 70-10; Apogee Instruments Inc., Logan, UT). The relative humidity in the culture room was $70 \pm 5 \%$. In each experiment, shoots were cultured under the same conditions as the establishment phase.

Experimental treatments. To compare explant collection dates and chilling duration, 'G.30' explants were collected on three different dates: 1) Aug. 2011 from trees placed in the greenhouse in Apr. 2011, 2) Nov. 2011 from the same stock plants, and 3) Apr. 2012 from a different set of trees that were placed in the greenhouse in Mar. 2012. Trees had been overwintered in a cold storage room at $1 \pm 1{ }^{\circ} \mathrm{C}$ from October to March in both years. Stock plants of 'G.41' failed to produce a sufficient number of shoots for this experiment. Nodal explants were cultured on establishment media in an incubator at a temperature of 4 to $6^{\circ} \mathrm{C}$ for $0,4,6$, or 8 weeks before moving into the culture room for a $40-\mathrm{d}$ establishment phase. After establishment culture, the newly sprouted shoots were cut off and then transferred into Magenta ${ }^{\mathrm{TM}}$ square vessels $\left(\mathrm{GA}-7,77 \times 77 \times 97 \mathrm{~mm}\right.$, Sigma $\left.{ }^{\circledR}\right)$ containing $50 \mathrm{~mL}$ fresh MS base media supplemented with $1.0 \mathrm{mg} \cdot \mathrm{L}^{-1} \mathrm{BA}, 0.1 \mathrm{mg} \cdot \mathrm{L}^{-1}$ IBA, and $0.5 \mathrm{mg} \cdot \mathrm{L}^{-1} \mathrm{GA}_{3}$ (Sigma Chemical Co., St. Louis, MO).

To compare cytokinin type and concentration, 'G.30' explants for establishing aseptic shoots were collected in May 2013 from trees planted in the greenhouse in Mar. 2013. Following the establishment phase, shoot cultures were transferred into GA-7 vessels containing $50 \mathrm{~mL}$ fresh MS media with $0.5 \mathrm{mg} \cdot \mathrm{L}^{-1} \mathrm{IBA}$ and $0.5 \mathrm{mg} \cdot \mathrm{L}^{-1} \mathrm{GA}_{3}$. The cytokinins BA, ZT, and TDZ were each tested at concentrations of $0,0.5,1.0$, or $2.0 \mathrm{mg} \cdot \mathrm{L}^{-1}$.

To compare different concentrations of BA and $\mathrm{GA}_{3}$, 'G.30' explants for establishing aseptic shoots were collected in early June 2013 from trees placed in greenhouse in Mar. 2013. Establishment and preparation of the newly sprouted shoots was done the same as in previous experiments. $\mathrm{GA}_{3}$ was added at concentrations of $0,0.5$, or $1.0 \mathrm{mg} \cdot \mathrm{L}^{-1}$ with BA at concentrations of $0,0.5$, or $2.0 \mathrm{mg} \cdot \mathrm{L}^{-1}$, and a constant level of $0.5 \mathrm{mg} \cdot \mathrm{L}^{-1}$ IBA. Concentration of $\mathrm{GA}_{3}$ at $0,1.0$, or $4.0 \mathrm{mg} \cdot \mathrm{L}^{-1}$ was tested again on explants collected in late June with IBA at $0.5 \mathrm{mg} \cdot \mathrm{L}^{-1}$ and $2.0 \mathrm{mg} \cdot \mathrm{L}^{-1}$ BA.

To compare concentrations of EBR, 'G.30' explants were collected in Apr. 2013 from trees placed in a greenhouse in Mar. 2013. Explants were aseptically established and prepared as in previous experiments and were transferred into GA-7 vessels containing $50 \mathrm{~mL}$ fresh MS media with $2.0 \mathrm{mg} \cdot \mathrm{L}^{-1}$ $\mathrm{BA}, 0.5 \mathrm{mg} \cdot \mathrm{L}^{-1} \mathrm{IBA}$, and $0,0.1$, or $1.0 \mathrm{mg} \cdot \mathrm{L}^{-1}$ of EBR.

To compare different chilling durations and $\mathrm{GA}_{3}$ concentrations, explants of ' $\mathrm{G} .41$ ' were collected in Apr. 2013 from trees placed in the greenhouse in Mar. 2013. Nodal explants were cultured on establishment media in an incubator at a temperature of $5 \pm$ $1^{\circ} \mathrm{C}$ for $0,4,6$, or 8 weeks before moving into the culture room for the establishment phase. After $40 \mathrm{~d}$ of establishment culture, the newly sprouted shoots were cut off and transferred into Magenta ${ }^{\mathrm{TM}}$ square vessels containing $50 \mathrm{~mL}$ fresh MS base media supplemented with $1.0 \mathrm{mg} \cdot \mathrm{L}^{-1} \mathrm{BA}$ and $0.1 \mathrm{mg} \cdot \mathrm{L}^{-1}$ IBA. Media also contained different concentrations of $\mathrm{GA}_{3}$ which were $0,0.5$, or $1.0 \mathrm{mg} \cdot \mathrm{L}^{-1}$.

To compare $\mathrm{GA}_{3}$ concentration in the first and second subculture, 'G.41' explants were collected in Apr. 2013 from trees placed in greenhouse in Mar. 2013. Explants were aseptically established and prepared as in previous experiments on media with $2.0 \mathrm{mg} \cdot \mathrm{L}^{-1} \mathrm{BA}$ and $0.5 \mathrm{mg} \cdot \mathrm{L}^{-1} \mathrm{IBA}$. Three concentrations of $\mathrm{GA}_{3}, 0,0.5$, and $1.0 \mathrm{mg} \cdot \mathrm{L}^{-1}$, were tested during the first and second subcultures, each at a duration of $40 \mathrm{~d}$, under the same conditions as the establishment phase. In a second experiment, explants were collected from the same trees in July and cultured under the same conditions as in April, but on media containing $\mathrm{GA}_{3}$ at 0 , $1.0,4.0$, and $8.0 \mathrm{mg} \cdot \mathrm{L}^{-1}$

Shoot growth measurements. After culturing for $40 \mathrm{~d}$ on proliferation media, the number of microshoots per explant, the length of the longest microshoot per explant, and the number of elongated microshoots were measured in each experiment. Elongation was defined as a minimum shoot length of $15 \mathrm{~mm}$. Shoots were characterized as elongated with a score of 1 or nonelongated with a score of 0 . For each treatment 
combination, the multiplication rate was calculated as the percentage of explants with two or more shoots and elongation rate as the percentage of microshoots with a shoot length of $15 \mathrm{~mm}$ or longer.

Data analysis. In all experiments, we used a completely randomized design with at least four replicates per treatment and eight explants per replicate. All data were analyzed using Statistical Analysis Systems (Version 9.3; SAS Institute Inc., Cary, NC). Analysis of variance was used to test for variation in the maximum in vitro shoot length. The multiplication and elongation rates were analyzed as binomial data, and the number of microshoots per explant was analyzed as negative binomial data. Means separation was carried out using Fisher's least significant difference method with an alpha of 0.05 .

\section{Results}

Chilling duration and explant collection date affected the number of 'G.30' shoots proliferated per explant, multiplication rate, shoot length, and the number of elongated shoots (Table 1). In unchilled explants, collection in April resulted in a greater number of shoots and a greater multiplication rate compared with August and November. Chilling explants collected in April did not increase the number of shoots or multiplication rate, but chilling for 8 weeks decreased both compared with no chilling. Chilling explants collected in August and November for 6 weeks increased shoot number, but other durations had no effect, whereas all three chilling durations increased the multiplication rate. Shoot elongation was generally greater with explants collected in April compared with August and November. In April, chilling for 4 weeks had no effect on shoot length or elongation rate, 6 weeks increased shoot length, but not the elongation rate, and 8 weeks decreased both. In August and November, 6 weeks of chilling increased shoot length and elongation rates, whereas 4 weeks increased only the elongation rate in August and 8 weeks had no effect on either. Chilling explants collected in August and November increased proliferation to the level that occurred with the April collection.

Type of cytokinin influenced 'G.30' shoot number, multiplication rate, shoot length, and elongation rate with an interaction with concentration (Table 2). The main effect of concentration was significant for shoot number, multiplication rate, and elongation rate, but not shoot length. The number of new shoots per explant and the multiplication rate were the poorest with no cytokinin in the media. For BA, there was a strong effect of concentration with $0.5 \mathrm{mg} \cdot \mathrm{L}^{-1}$ having no effect on shoot number, $1.0 \mathrm{mg} \cdot \mathrm{L}^{-1}$ slightly increasing it, and $2.0 \mathrm{mg} \cdot \mathrm{L}^{-1}$ resulting in the largest number of shoots compared with lower concentrations of BA and all rates of TDZ and ZT. Benzyladenine at $2.0 \mathrm{mg} \cdot \mathrm{L}^{-1}$ resulted in a greater multiplication rate and shoot length than lower concentrations, but the elongation rate was similar to the rate that

Table 1. In vitro shoot growth of 'G.30' apple from three explant collection dates and following chilling explants at $5 \pm 1{ }^{\circ} \mathrm{C}$ for varying durations.

\begin{tabular}{|c|c|c|c|c|c|}
\hline Date $^{z}$ & Chilling (wk.) & $\begin{array}{c}\text { No. of } \\
\text { shoots/explant }\end{array}$ & $\begin{array}{l}\text { Multiplication } \\
\text { rate }(\%)^{\mathrm{y}}\end{array}$ & $\begin{array}{c}\text { Shoot } \\
\text { length }(\mathrm{mm})\end{array}$ & $\begin{array}{l}\text { Elongation } \\
\text { rate }(\%)^{x}\end{array}$ \\
\hline \multirow[t]{4}{*}{ Apr. 2012} & 0 & $3.0 \mathrm{ab}^{\mathrm{w}}$ & $78 \mathrm{ab}$ & $21 \mathrm{bc}$ & $78 \mathrm{ab}$ \\
\hline & 4 & $2.4 \mathrm{abc}$ & $86 \mathrm{a}$ & $22 \mathrm{ab}$ & $71 \mathrm{abc}$ \\
\hline & 6 & $3.4 \mathrm{a}$ & $83 \mathrm{a}$ & $26 \mathrm{a}$ & $92 \mathrm{a}$ \\
\hline & 8 & $1.5 \mathrm{c}$ & $44 \mathrm{~cd}$ & $16 \mathrm{de}$ & $62 \mathrm{bcd}$ \\
\hline \multirow[t]{4}{*}{ Aug. 2011} & 0 & $1.5 \mathrm{c}$ & $19 \mathrm{~d}$ & 13 e & $45 \mathrm{~d}$ \\
\hline & 4 & $2.1 \mathrm{bc}$ & $73 \mathrm{ab}$ & 18 cde & $73 a b c$ \\
\hline & 6 & $2.7 \mathrm{~b}$ & $73 \mathrm{ab}$ & $21 \mathrm{bc}$ & $76 \mathrm{abc}$ \\
\hline & 8 & $1.9 \mathrm{c}$ & $59 \mathrm{bc}$ & $16 \mathrm{de}$ & $52 \mathrm{~cd}$ \\
\hline \multirow[t]{4}{*}{ Nov. 2011} & 0 & $1.9 \mathrm{c}$ & $32 \mathrm{~d}$ & $11 \mathrm{e}$ & $37 \mathrm{de}$ \\
\hline & 4 & $2.0 \mathrm{bc}$ & $54 \mathrm{bc}$ & $13 \mathrm{e}$ & $27 \mathrm{e}$ \\
\hline & 6 & $2.9 \mathrm{ab}$ & $73 \mathrm{ab}$ & $19 \mathrm{~cd}$ & $78 \mathrm{ab}$ \\
\hline & 8 & $1.9 \mathrm{c}$ & $61 \mathrm{bc}$ & $16 \mathrm{de}$ & $61 \mathrm{bcd}$ \\
\hline \multicolumn{6}{|l|}{ Significance } \\
\hline \multicolumn{2}{|c|}{ Date } & $* * *$ & $* * *$ & $* * *$ & $* *$ \\
\hline \multicolumn{2}{|c|}{ Chilling } & $* * *$ & *** & $* * *$ & *** \\
\hline \multicolumn{2}{|c|}{ Date $\times$ chilling } & NS & $* * *$ & $*$ & NS \\
\hline
\end{tabular}

${ }^{\mathrm{z}}$ Explants were collected in Apr. 20121 month after budbreak; in Aug. and Nov. 2011, 4 and 7 months after budbreak, respectively.

yPercentage of explants with two or more new shoots.

xPercentage of shoots with a shoot length equal to or longer than $15 \mathrm{~mm}$.

"Means followed by the same letter in each column are not significantly different by Fishers least significant difference test at $\alpha=0.05$ level.

Ns, ${ }^{*},{ }^{* *},{ }^{* * *}$ Nonsignificant or significant at $P \leq 0.05,0.01$, or 0.001 , respectively.

Table 2. In vitro shoot growth of 'G.30' apple on media with three different cytokinins.

\begin{tabular}{lccccc}
\hline Cytokinin type & Concn $\left(\mathrm{mg} \cdot \mathrm{L}^{-1}\right)$ & $\begin{array}{c}\text { No. of } \\
\text { shoots/explant }\end{array}$ & $\begin{array}{c}\text { Multiplication } \\
\text { rate }(\%)^{\mathrm{z}}\end{array}$ & $\begin{array}{c}\text { Shoot } \\
\text { length }(\mathrm{mm})\end{array}$ & $\begin{array}{c}\text { Elongation } \\
\text { rates }(\%)^{\mathrm{y}}\end{array}$ \\
\hline None & 0.0 & $1.0 \mathrm{e}^{\mathrm{x}}$ & $0 \mathrm{~d}$ & $9 \mathrm{~d}$ & $0 \mathrm{~d}$ \\
$\mathrm{BA}$ & 0.5 & $2.4 \mathrm{de}$ & $68 \mathrm{~b}$ & $14 \mathrm{c}$ & $50 \mathrm{~b}$ \\
& 1.0 & $3.8 \mathrm{~d}$ & $74 \mathrm{~b}$ & $21 \mathrm{~b}$ & $79 \mathrm{a}$ \\
TDZ & 2.0 & $10.6 \mathrm{a}$ & $100 \mathrm{a}$ & $25 \mathrm{a}$ & $90 \mathrm{a}$ \\
& 0.5 & $7.2 \mathrm{~b}$ & $100 \mathrm{a}$ & $3 \mathrm{e}$ & $0 \mathrm{~d}$ \\
ZT & 1.0 & $8.3 \mathrm{~b}$ & $100 \mathrm{a}$ & $3 \mathrm{e}$ & $0 \mathrm{~d}$ \\
& 2.0 & $7.3 \mathrm{~b}$ & $100 \mathrm{a}$ & $3 \mathrm{e}$ & $0 \mathrm{~d}$ \\
& 0.5 & $5.4 \mathrm{c}$ & $100 \mathrm{a}$ & $14 \mathrm{c}$ & $26 \mathrm{c}$ \\
Significance & 1.0 & $2.3 \mathrm{e}$ & $78 \mathrm{~b}$ & $16 \mathrm{c}$ & $50 \mathrm{~b}$ \\
$\quad$ Type & 2.0 & $1.5 \mathrm{e}$ & $27 \mathrm{c}$ & $9 \mathrm{~d}$ & $0 \mathrm{~d}$ \\
Concn & & $* * *$ & $* * *$ & $* * *$ & $* * *$ \\
Type $\times$ concn & & $* * *$ & $*$ & NS & $*$ \\
BA & & $* *$ & $* *$ & $* * *$ & $* * *$ \\
\hline
\end{tabular}

$\mathrm{BA}=6$-benzylaminopurine; TDZ $=$ N-phenyl-N'-(1,2,3-thiadiazol-5-yl)urea; ZT $=$ 6-(4-hydroxy-3methylbut-2-enylamino)purine.

${ }^{2}$ Percentage of explants with two or more new shoots.

${ }^{y}$ Percentage of shoots with a shoot length equal to or longer than $15 \mathrm{~mm}$.

${ }^{x}$ Means followed by the same letter in each column are not significantly different by Fishers least significant difference test at $\alpha=0.05$ level.

${ }_{\mathrm{Ns},}^{*}, * * *$ Nonsignificant or significant at $P \leq 0.05$ or 0.001 , respectively.

occurred with $1 \mathrm{mg} \cdot \mathrm{L}^{-1}$ of BA. However, BA at $2.0 \mathrm{mg} \cdot \mathrm{L}^{-1}$ resulted in a multiplication rate similar to TDZ. For TDZ, there was no concentration effect on shoot growth at the rates tested in this experiment. The number of shoots per explant and the multiplication rates were generally good with TDZ, but shoot length was the shortest and none of the shoots grew in length more than $15 \mathrm{~mm}$. $\mathrm{ZT}$ increased shoot number at the lowest concentration, but higher concentrations had no effect compared with no cytokinin. Multiplication rate was also increased by $\mathrm{ZT}$ at the two lower rates compared with no cytokinin. With 0.5 and $1.0 \mathrm{mg} \cdot \mathrm{L}^{-1} \mathrm{ZT}$, shoot length was similar to $0.5 \mathrm{mg} \cdot \mathrm{L}^{-1} \mathrm{BA}$, but was shorter than BA at 1.0 to $2.0 \mathrm{mg} \cdot \mathrm{L}^{-1}$. Shoot length with the highest rate of ZT was similar to no cytokinin. At equivalent concentrations, the elongation rate with $\mathrm{ZT}$ was less than with BA, but at 0.5 and $1.0 \mathrm{mg} \cdot \mathrm{L}^{-1}$ was greater than equivalent concentrations of TDZ.

In 'G.30' explants collected in early June, $\mathrm{GA}_{3}$ concentration of 0 to $1.0 \mathrm{mg} \cdot \mathrm{L}^{-1}$ had no effect on shoot growth (Table 3 ). Increasing BA concentration increased shoot number, multiplication rate, shoot length, and elongation rate. Both 0.5 and $2.0 \mathrm{mg} \cdot \mathrm{L}^{-1}$ of $\mathrm{BA}$ increased shoot growth compared with $0 \mathrm{mg} \cdot \mathrm{L}^{-1}$, and shoot growth was greater at the higher concentration. On media with no BA, shoot growth was poor. An interaction between $\mathrm{BA}$ and $\mathrm{GA}_{3}$ occurred for their effect on shoot elongation. On media with no $\mathrm{GA}_{3}$, the higher concentration of $\mathrm{BA}$ did not further increase the elongation rate compared with $0.5 \mathrm{mg} \cdot \mathrm{L}^{-1}$, but with $\mathrm{GA}_{3}$ in the media, there was an increase in the elongation rate with the higher rate of BA. Concentration of $\mathrm{GA}_{3}$ from 0 to $1.0 \mathrm{mg} \cdot \mathrm{L}^{-1}$ had 
almost no effect on 'G.30' explants collected in late June (data not shown).

EBR negatively affected the shoot growth of 'G.30' (Table 4). Shoot growth significantly decreased with both concentrations of EBR, and the higher concentration decreased shoot growth more than the lower concentration.

Shoot growth of 'G.41' was poor (Table 5) compared with 'G.30', and chilling and $\mathrm{GA}_{3}$ had very little impact on its shoot growth. There was an interaction between the two factors in their effect on the number of shoots per explant and the multiplication rate. Chilling for 4 weeks slightly increased the number of shoots and the multiplication rate, but only with no $\mathrm{GA}_{3}$ added to the media. Concentrations of $\mathrm{GA}_{3}$ at 0.5 and $1.0 \mathrm{mg} \cdot \mathrm{L}^{-1}$ had no effect on shoot number or multiplication with any duration of chilling. Shoot length and the number of elongated shoots were unaffected by chilling duration up to 8 weeks or by $\mathrm{GA}_{3}$ concentration up to $1.0 \mathrm{mg} \cdot \mathrm{L}^{-1}$. Collection date was not tested on 'G.41', and all 'G.41' explants were collected in April.

When concentration of $\mathrm{GA}_{3}$ was tested on ' $G .41$ ', it had no effect on shoot growth during the first or second subculture (Table 6). Shoot multiplication and elongation were low during the first subculture, but were increased by an additional subculture on proliferation media. From explants collected in July, shoot multiplication and elongation were as low as the April collection date during first subculture and were unaffected by any concentration of $\mathrm{GA}_{3}$ from 0 to $10 \mathrm{mg} \cdot \mathrm{L}^{-1}$ (data not shown; Geng, 2014).

\section{Discussion}

Commercial application of apple micropropagation is limited by inefficient multiplication rates which range from four to six new shoots per explant in a regular 1-month subculture for most cultivars (Druart, 2003). Shoot proliferation of 'G.41' was poor and was not improved by the addition of $\mathrm{GA}_{3}$ or chilling. Additional time in culture that occurs with subculturing can increase propagation efficiency (Kane, 2005; Webster and Jones, 1991) and was an important factor for increasing proliferation of ' $\mathrm{G} .41$ ' from 1.3 to 5.2 , but shoot elongation rates remained below $50 \%$. Slow development from lateral buds that is overcome by additional time in culture may indicate incomplete development (Hauagge and Cummins, 1991a). Although collection dates were not directly compared for 'G.41', proliferation from explants was poor in both experiments conducted in 2013 when explants were collected in April and July. Other times were not tested for ' $G .41$ ' since stock plants grown in the greenhouse often failed to maintain active shoot growth after the first flush of new shoots, so there was insufficient new growth for additional explants. After the initial flush of shoot elongation, they formed a terminal bud and failed to elongate, and when shoot tips were removed, they failed to branch.

The condition of stock plants appeared to be one of the most important factors

Table 3. In vitro shoot growth of 'G.30' apple on media with different concentrations of gibberellic acid $\left(\mathrm{GA}_{3}\right)$ and 6-benzylaminopurine (BA).

\begin{tabular}{|c|c|c|c|c|c|}
\hline $\mathrm{GA}_{3}\left(\mathrm{mg} \cdot \mathrm{L}^{-1}\right)$ & $\mathrm{BA}\left(\mathrm{mg} \cdot \mathrm{L}^{-1}\right)$ & $\begin{array}{c}\text { No. of } \\
\text { shoots/explant }\end{array}$ & $\begin{array}{l}\text { Multiplication } \\
\text { rate }(\%)^{\mathrm{z}}\end{array}$ & $\begin{array}{c}\text { Shoot } \\
\text { length }(\mathrm{mm})\end{array}$ & $\begin{array}{l}\text { Elongation } \\
\text { rate }(\%)^{\mathrm{y}}\end{array}$ \\
\hline \multirow[t]{3}{*}{0.0} & 0.0 & $1.0 \mathrm{c}^{\mathrm{x}}$ & $0 \mathrm{c}$ & $8 \mathrm{c}$ & $7 \mathrm{c}$ \\
\hline & 0.5 & $2.7 \mathrm{~b}$ & $67 \mathrm{~b}$ & $14 \mathrm{~b}$ & $61 \mathrm{~b}$ \\
\hline & 2.0 & $6.6 \mathrm{a}$ & $100 \mathrm{a}$ & $17 \mathrm{ab}$ & $50 \mathrm{~b}$ \\
\hline \multirow[t]{3}{*}{0.5} & 0.0 & $1.0 \mathrm{c}$ & $0 \mathrm{c}$ & $5 \mathrm{c}$ & $0 \mathrm{c}$ \\
\hline & 0.5 & $3.3 \mathrm{~b}$ & $79 \mathrm{~b}$ & $17 \mathrm{ab}$ & $50 \mathrm{~b}$ \\
\hline & 2.0 & $6.3 \mathrm{a}$ & $100 \mathrm{a}$ & $19 \mathrm{a}$ & 93 a \\
\hline \multirow[t]{3}{*}{1.0} & 0.0 & $1.0 \mathrm{c}$ & $0 \mathrm{c}$ & $6 \mathrm{c}$ & $0 \mathrm{c}$ \\
\hline & 0.5 & $2.9 \mathrm{~b}$ & $79 \mathrm{~b}$ & $16 \mathrm{ab}$ & $71 \mathrm{~b}$ \\
\hline & 2.0 & $5.8 \mathrm{a}$ & $100 \mathrm{a}$ & $18 \mathrm{a}$ & $88 \mathrm{a}$ \\
\hline \multicolumn{6}{|l|}{ Significance } \\
\hline $\mathrm{GA}_{3}$ & & NS & NS & NS & NS \\
\hline $\mathrm{BA}$ & & $* * *$ & $* * *$ & $* * *$ & $* * *$ \\
\hline $\mathrm{GA}_{3} \times \mathrm{BA}$ & & NS & NS & NS & $*$ \\
\hline
\end{tabular}

${ }^{2}$ Percentage of explants with two or more new shoots.

yPercentage of shoots with a shoot length equal to or longer than $15 \mathrm{~mm}$.

${ }^{x}$ Means followed by the same letter in each column are not significantly different by Fishers least significant difference test at $\alpha=0.05$ level.

Ns, ${ }^{*}, * * *$ Nonsignificant or significant at $P \leq 0.05$, or 0.001 , respectively.

Table 4. In vitro shoot growth of 'G.30' apple on media with different concentrations of epi-brassinolide (EBR).

\begin{tabular}{lcccc}
\hline EBR $\left(\mathrm{mg} \cdot \mathrm{L}^{-1}\right)$ & $\begin{array}{c}\text { No. of } \\
\text { shoots/explant }\end{array}$ & $\begin{array}{c}\text { Multiplication } \\
\text { rate }(\%)^{\mathrm{z}}\end{array}$ & $\begin{array}{c}\text { Shoot } \\
\text { length }(\mathrm{mm})\end{array}$ & $\begin{array}{c}\text { Elongation } \\
\text { rates }(\%)^{\mathrm{y}}\end{array}$ \\
\hline 0.0 & $4.1 \mathrm{a}^{\mathrm{x}}$ & $93 \mathrm{a}$ & $18 \mathrm{a}$ & $69 \mathrm{a}$ \\
0.1 & $2.7 \mathrm{~b}$ & $84 \mathrm{a}$ & $11 \mathrm{~b}$ & $36 \mathrm{~b}$ \\
1.0 & $1.8 \mathrm{c}$ & $49 \mathrm{~b}$ & $5 \mathrm{c}$ & $7 \mathrm{c}$ \\
Significance & $* * *$ & $* * *$ & $* * *$ & $* * *$ \\
\hline
\end{tabular}

${ }^{2}$ Percentage of explants with two or more new shoots.

yPercentage of shoots with a shoot length equal to or longer than $15 \mathrm{~mm}$.

${ }^{x}$ Means followed by the same letter in each column are not significantly different by Fishers least significant difference test at $\alpha=0.05$ level.

${ }^{* * *}$ Significant at $P \leq 0.001$.

Table 5. In vitro shoot growth of ' $\mathrm{G} .41$ ' apple following chilling at $5 \pm 1{ }^{\circ} \mathrm{C}$ and culturing on media with different gibberellic acid $\left(\mathrm{GA}_{3}\right)$ concentrations.

\begin{tabular}{|c|c|c|c|c|c|}
\hline $\mathrm{GA}_{3}\left(\mathrm{mg} \cdot \mathrm{L}^{-1}\right)$ & Chilling (wk.) & $\begin{array}{c}\text { No. of } \\
\text { shoots/explant }\end{array}$ & $\begin{array}{l}\text { Multiplication } \\
\text { rate }(\%)^{\mathrm{z}}\end{array}$ & $\begin{array}{c}\text { Shoot } \\
\text { length }(\mathrm{mm})\end{array}$ & $\begin{array}{l}\text { Elongation } \\
\text { rate }(\%)^{\mathrm{y}}\end{array}$ \\
\hline \multirow[t]{4}{*}{0.0} & 0 & $1.3 \mathrm{~b}^{\mathrm{x}}$ & $12 \mathrm{~b}$ & 4 & 0 \\
\hline & 4 & $1.6 \mathrm{a}$ & $38 \mathrm{a}$ & 6 & 0 \\
\hline & 6 & $1.0 \mathrm{~b}$ & $0 \mathrm{~b}$ & 6 & 0 \\
\hline & 8 & ${ }^{\mathrm{w}}$ & - & - & - \\
\hline \multirow[t]{4}{*}{0.5} & 0 & $1.0 \mathrm{~b}$ & $0 \mathrm{~b}$ & 3 & 0 \\
\hline & 4 & $1.0 \mathrm{~b}$ & $0 \mathrm{~b}$ & 3 & 0 \\
\hline & 6 & $1.0 \mathrm{~b}$ & $0 \mathrm{~b}$ & 6 & 0 \\
\hline & 8 & $1.0 \mathrm{~b}$ & $0 \mathrm{~b}$ & 8 & 0 \\
\hline \multirow[t]{4}{*}{1.0} & 0 & $1.3 \mathrm{ab}$ & $23 \mathrm{ab}$ & 5 & 0 \\
\hline & 4 & $1.0 \mathrm{~b}$ & $0 \mathrm{~b}$ & 5 & 0 \\
\hline & 6 & $1.2 \mathrm{~b}$ & $19 \mathrm{ab}$ & 5 & 0 \\
\hline & 8 & $1.1 \mathrm{~b}$ & $7 \mathrm{~b}$ & 7 & 11 \\
\hline \multicolumn{6}{|l|}{ Significance } \\
\hline $\mathrm{GA}_{3}$ & & NS & NS & NS & NS \\
\hline Chilling & & NS & NS & NS & NS \\
\hline $\mathrm{GA}_{3} \times$ chilling & & $* *$ & $* *$ & NS & NS \\
\hline
\end{tabular}

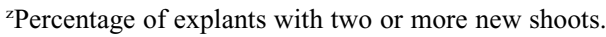

yPercentage of shoots with a shoot length equal to or longer than $15 \mathrm{~mm}$.

${ }^{x}$ Means followed by the same letter in each column are not significantly different by Fishers least significant difference test at $\alpha=0.05$ level.

${ }^{w}$ Means not available.

Ns, ** Nonsignificant or significant at $P \leq 0.01$, respectively.

controlling ' $G .30$ ' micropropagation efficiency in this study. Although it was tested in two different years, shoot multiplication and elongation of ' $\mathrm{G} .30$ ' were the greatest when explants were collected in Apr. 2012 compared with Aug. and Nov. 2011. In 2012, explants collected in July for a subsequent experiment had similar multiplication and elongation rates as April (Tables 1 and 2). In 2013, explants collected at different times also displayed a seasonal variation in shoot proliferation and elongation that varied somewhat from the previous year. A high degree of variation occurred in the number of new shoots per explant with 3.8 in April, 10.6 in May, 6.6 in early June, and 1.8 in late June 
Table 6. In vitro shoot growth of 'G.41' apple during first and second subculture on media with different concentrations of gibberellic acid $\left(\mathrm{GA}_{3}\right)$.

\begin{tabular}{lccccc}
\hline Main effect & First & $\begin{array}{c}\text { No. of } \\
\text { shoots/explant }\end{array}$ & $\begin{array}{c}\text { Multiplication } \\
\text { rate }(\%)^{\mathrm{z}}\end{array}$ & $\begin{array}{c}\text { Shoot } \\
\text { length }(\mathrm{mm})\end{array}$ & $\begin{array}{c}\text { Elongation } \\
\text { rate }(\%)^{\mathrm{y}}\end{array}$ \\
\hline Subculture & $1.5 \mathrm{~b}^{\mathrm{x}}$ & $40 \mathrm{~b}$ & $1 \mathrm{~b}$ & $0 \mathrm{~b}$ \\
& Second & $4.2 \mathrm{a}$ & $100 \mathrm{a}$ & $12 \mathrm{a}$ & $30 \mathrm{a}$ \\
$\mathrm{GA}_{3}\left(\mathrm{mg} \cdot \mathrm{L}^{-1}\right)$ & 0.0 & 2.8 & 73 & 6 & 7 \\
& 0.5 & 2.9 & 81 & 7 & 19 \\
Significance & 1.0 & 3.5 & 70 & 9 & 25 \\
Subculture & & $* * *$ & $* * *$ & $* * *$ & $* *$ \\
$\mathrm{GA}_{3}$ & $\mathrm{NS}$ & $\mathrm{NS}$ & $\mathrm{NS}$ & $\mathrm{NS}$ \\
Subculture $\times \mathrm{GA}_{3}$ & $\mathrm{NS}$ & $\mathrm{NS}$ & $\mathrm{NS}$ & $\mathrm{NS}$ \\
\hline
\end{tabular}

${ }^{2}$ Percentage of explants with two or more new shoots.

'Percentage of shoots with a shoot length equal to or longer than $15 \mathrm{~mm}$.

${ }^{\mathrm{x}}$ Means followed by the same letter in each column are not significantly different by Fishers least significant difference test at $\alpha=0.05$ level.

Ns, ${ }^{* *}, * * *$ Nonsignificant or significant at $P \leq 0.01$ or 0.001 , respectively.

despite the use of the same stock plants, culture room conditions, and media constituents. This seasonal reduction in summer in the ability to proliferate may indicate that axillary buds had acquired a level of dormancy by those collection dates (Fuchigami and Nee, 1987). Temperatures above $20^{\circ} \mathrm{C}$ induce terminal bud set and dormancy in apple buds (Hauagge and Cummins, 1991a, 1991b). In our study, stock plants were grown in a greenhouse where temperatures were at times above $30^{\circ} \mathrm{C}$, which may have contributed to the poor proliferation in summer and fall.

Cultivar 'G.30' exhibited complex responses to chilling treatments. Six weeks of chilling in spring did not increase shoot multiplication of ' $\mathrm{G} .30$ ', but chilling in summer or fall increased proliferation to the same level as occurred with April. Shoot elongation was increased by chilling explants for 6 weeks regardless of when they were collected, but explants collected in August and November were slightly shorter compared with April explantation. Most apple cultivars have a minimum chilling requirement of about $1000 \mathrm{~h}$ (6 weeks) or more for terminal budbreak, but additional budbreak occurs with additional chilling (Hauagge and Cummins, 1991a; Heide and Prestrud, 2005). This did not occur with 'G.30' since 8 weeks of chilling inhibited shoot growth compared with shorter durations. Rather than displaying signs of full dormancy that involve leaf abscission, the shoot tips continued to form and unfold new leaves without shoot elongation, giving the shoots a rosette appearance similar to what has been described in greenhouse grown apple shoots that sprout in November before any chilling temperatures (Hauagge and Cummins, 1991a). Chilling for at least 6 weeks was the most effective duration for 'G.30' for promoting shoot elongation, but additional chilling time appeared to be detrimental for unknown reasons.

The addition of phytohormones to media resulted in proliferation and growth similar to those reported for other apple cultivars with some notable exceptions. The addition of cytokinin is essential for adequate proliferation of apple shoots (Elliott, 1972) and is typically added to proliferation media (Kane, 2005). For 'G.30', all three cytokinins tested were effective for increasing shoot number, but BA was more effective at the concentrations tested and also increased shoot elongation to a greater extent than ZT or TDZ. As in previous studies (Hutchinson, 1984; van Nieuwkerk et al., 1986), TDZ inhibited elongation but concentrations in our study may have been supraoptimal (Huetteman and Preece, 1993). As reported for 'Golden Delicious' by Lundergan and Janick (1980), ZT increased shoot growth of ' $\mathrm{G} .30$ ', but only at concentrations of $1.0 \mathrm{mg} \cdot \mathrm{L}^{-1}$ or lower.

The optimal BA concentration varies with cultivar, but is generally 1.0 to $2.0 \mathrm{mg} \cdot \mathrm{L}^{-1}$ for apple (Hutchinson, 1984; James and Thurbon, 1981; Lane and McDougald, 1982; Pua et al., 1983). For 'G.30', the most effective concentration was $2.0 \mathrm{mg} \cdot \mathrm{L}^{-1}$ which increased the number of new shoots and shoot length compared with lower or higher levels. Optimum concentration also depends on the seasonal time when explants are collected with concentrations between 2.0 and $5.0 \mathrm{mg} \cdot \mathrm{L}^{-1}$ being more effective than greater concentrations for 'Golden Delicious' explants collected at the start of shoot growth and concentrations below $5.0 \mathrm{mg} \cdot \mathrm{L}^{-1}$ being ineffective for explants collected at the end of the shoot growth phase (Brand, 1993). In our study, $2.0 \mathrm{mg} \cdot \mathrm{L}^{-1} \mathrm{BA}$ was consistently effective for proliferation with explants collected from greenhouse-grown trees in July 2012, and May and June 2013.

The effect of $\mathrm{GA}_{3}$ on shoot elongation was small compared with other factors such as explant date, chilling, and cytokinin, and was dependent on the concentration of BA. $\mathrm{GA}_{3}$ increased shoot elongation when combined with the optimum BA concentration of $2.0 \mathrm{mg} \cdot \mathrm{L}^{-1}$. In addition, high $\mathrm{GA}_{3}$ concentration was detrimental to multiplication indicating that it was supraoptimal at $4.0 \mathrm{mg} \cdot \mathrm{L}^{-1}$.

In determining an effective dose of EBR as a media constituent in 'G.30', we found both doses 0.1 and $1.0 \mathrm{mg} \cdot \mathrm{L}^{-1}$ to be inhibitory to shoot elongation. In contrast, EngelmannSylvestre and Engelmann (2013) found a media concentration of $0.05 \mathrm{mg} \cdot \mathrm{L}^{-1}$ slightly increased shoot elongation in yam. In $C$. annuum, increase in shoot elongation at this dose is inconsistent, cultivar dependent, and sometimes inhibitory when combined with cytokinin (Franck-Duchenne et al., 1998). Additional work is needed to refine the use of EBR for promoting shoot elongation in apple micropropagation.

Initial shoot multiplication and elongation were highly variable between the two genotypes, experimental treatments, and in vitro conditions. The poor micropropagation efficiency of 'G.41' was overcome by an additional month in culture, and was not overcome by a chilling treatment or by increasing $\mathrm{GA}_{3}$ concentration in the media. 'G.30' also demonstrated poor efficiency when explants were collected in summer or fall compared with spring. This was overcome somewhat by chilling explants for 6 weeks. Type of cytokinin and its concentration had a large effect on shoot growth with BA being the most effective type and at a concentration of $2.0 \mathrm{mg} \cdot \mathrm{L}^{-1}$. The plant growth regulator $\mathrm{GA}_{3}$ had little effect on shoot growth, and EBR was inhibitory at concentrations tested in this study.

\section{Literature Cited}

Aklan, K., S. Çetiner, Y. Aka-Kaçar, and Y. YalçinMendi. 1997. In vitro multiplication of clonal apple rootstocks M-9, M-26 and MM-106 by meristem culture. Acta Hort. 441:325-327.

Borkowska, B. 1986. Dormancy of micropropagated sour cherry plantlets. Tree Physiol. 1: 303-307.

Bouza, L., M. Jacques, Y. Mazière, and Y. Arnaud. 1992. In vitro propagation of Prunus tenella Batsch. cv. 'Firehill': Control of vitrification; increase of the multiplication rate and growth by chilling. Sci. Hort. 52:143-155.

Brand, M.H. 1993. Initiating cultures of Halesia and Malus: Influence of flushing stage and benzyladenine. Plant Cell Tissue Organ Cult. 33:129-132.

De Klerk, G.J. 1992. Hormonal control of dormancy and apical dominance in tissue-cultured plants. Acta Bot. Neerl. 41:443-451.

Druart, P. 2003. Micropropagation of apples (Malus sp.), p. 433-463. In: S.M. Jain and K. Ishii (eds.). Micropropagation of woody trees and fruits. Kluwer Academic Publishers, Berlin, Germany.

Elliott, R.F. 1972. Axenic culture of shoot apices of apple. N.Z. J. Bot. 10:254-258

Engelmann-Sylvestre, I. and F. Engelmann. 2013. Effect of 24-epibrassinolide on growth of in vitro shoot tips of different yam (Dioscorea spp.) species. Amer. J. Plant Sci. 4:2271-2274.

Franck-Duchenne, M., Y. Wang, S. Ben Tahar, and R. Beachy. 1998. In vitro stem elongation of sweet pepper in media containing 24-epi-brassinolide. Plant Cell Tissue Organ Cult. 53:79-84.

Fuchigami, L. and C. Nee. 1987. Degree growth stage model and rest-breaking mechanisms in temperate woody perennials. HortScience 22: 836-845.

Geng, F. 2014. Enhancing micropropagation efficiency of apple rootstocks by identifying limitations of microshoot elongation. University of Maine, Orono, PhD Diss.

Geng, F., R. Moran, M. Day, W. Halteman, and D. Zhang. 2015. In vitro shoot proliferation of apple rootstocks 'B.9', 'G.30', and 'G.41' grown under red and blue light. HortScience 50: 430-433.

Hauagge, R. and J. Cummins. 1991a. Seasonal variation in intensity of bud dormancy in apple cultivars and related Malus species. J. Amer. Soc. Hort. Sci. 116:107-115. 
Hauagge, R. and J. Cummins. 1991b. Age, growing temperatures, and growth retardants influence induction and length of dormancy in Malus. J. Amer. Soc. Hort. Sci. 116:116-120.

Heide, O.M. and A.K. Prestrud. 2005. Low temperature, but not photoperiod, controls growth cessation and dormancy induction and release in apple and pear. Tree Physiol. 25:109-114.

Howard, B.H. and V.H. Oehl. 1981. Improved establishment of in vitro-propagated plum micropropagules following treatment with $\mathrm{GA}_{3}$ or prior chilling. J. Hort. Sci. 56:1-7.

Huetteman, C.A. and J.E. Preece. 1993. Thidiazuron: A potent cytokinin for woody plant tissue culture. Plant Cell Tissue Organ Cult. 33:105-119.

Hutchinson, J. 1984. Factors affecting shoot proliferation and root initiation in organ cultures of the apple 'Northern Spy'. Sci. Hort. 22:347-358.

Isutsa, D.K., M.P. Pritts, and K.W. Mudge. 1998. A protocol for rooting and growing apple rootstock microshoots. Fruit Var. J. 52:107-116.

James, D.J. and I.J. Thurbon. 1981. Shoot and root initiation in vitro in the apple rootstock M.9 and the promotive effects of phloroglucinol. J. Hort. Sci. 56:15-20.

Kane, M.E. 2005. Shoot culture procedures, p. 154-157. In: R. Trigiano and D. Gray (eds.). Plant development and biotechnology. CRC Press, Boca Raton, FL.
Kavanagh, K.L., D.H. Lee, A.P. Drew, and C.A. Maynard. 1993. The effects of $\mathrm{GA}_{3}$ and organic solvents on acclimatization of tissue culture propagated black cherry (Prunus serotina Ehrh.) plantlets. For. Sci. 39:644-654.

Kereša, S., A. Mihovilović Bošnjak, M. Barić, I. Habuš Jerčić, H. Sarčević, and A. Biško. 2012. Efficient axillary shoot proliferation and in vitro rooting of apple cv. 'Topaz'. Not. Bot. Horti Agrobo. 40:113-118.

Koubouris, G. and M. Vasilakakis. 2006. Improvement of in vitro propagation of apricot cultivar 'Bebecou'. Plant Cell Tissue Organ Cult. 85:173-180.

Lane, W.D. and J.M. McDougald. 1982. Shoot tissue culture of apple: Comparative response of five cultivars to cytokinins and auxin. Can. J. Plant Sci. 62:689-694.

Lundergan, C. and J. Janick. 1980. Regulation of apple shoot proliferation and growth in vitro. Hort. Res. 20:19-24.

Marin, J.A., O.P. Jones, and W.C.C. Hadlow. 1993. Micropropagation of columnar apple trees. J. Hort. Sci. 68:289-297.

Modgil, M., D.R. Sharma, and S.V. Bhardwaj. 1999. Micropropagation of apple cv. Tydeman's Early Worcester. Sci. Hort. 81:179-188.

Murashige, T. and F. Skoog. 1962. A revised medium for rapid growth and bio-assays with tobacco tissue cultures. Physiol. Plant. 15:473-497.
Pua, E., C. Chong, and G.L. Rousselle. 1983. In vitro propagation of Ottawa 3 apple rootstock. Can. J. Plant Sci. 63:183-188.

Reeves, D.W., G.A. Couvillon, and B.D. Horton 1985. Effect of gibberellic acid $\left(\mathrm{GA}_{3}\right)$ on elongation and rooting of 'St. Julien A' rootstock in vitro. Sci. Hort. 26:253-259.

Schaefer, S., S.A. Medeiro, J.A. Ramirez, L.R. Galagovsky, and A.B. Pereira-Netto. 2002. Brassinosteroid-driven enhancement of the in vitro multiplication rate for the marubakaido apple rootstock [Malus prunifolia (Willd.) Borkh.]. Plant Cell Rpt. 20:1093-1097.

van Nieuwkerk, J.P., R.H. Zimmerman, and I. Fordham. 1986. Thidiazuron stimulation of apple shoot proliferation in vitro. HortScience 21:516-524.

Webster, C.A. and O.P. Jones. 1991. Micropropagation of some cold-hardy dwarfing rootstocks for apple. J. Hort. Sci. 66:1-6.

Wu, J.H., S. Miller, H. Hall, and P. Mooney. 2009. Factors affecting the efficiency of micropropagation from lateral buds and shoot tips of Rubus. Plant Cell Tissue Organ Cult. 99: 17-25.

Yepes, L.M. and H.S. Aldwinckle. 1994. Micropropagation of thirteen Malus cultivars and rootstocks, and effect of antibiotics on proliferation. Plant Growth Regulat. 15:55-67. 